\title{
Involvement of endothelial CK2 in the radiation induced perivascular resistant niche (PVRN) and the induction of radioresistance for non-small cell lung cancer (NSCLC) cells
}

Qianwen Li ${ }^{1}$, Yan Zong ${ }^{1}, \mathrm{Ke} \mathrm{Li}^{2}$, Xiaohua Jie ${ }^{1}$, Jiaxin Hong ${ }^{1}$, Xiaoshu Zhou' ${ }^{1}$ Bian Wu' ${ }^{1}$ Zhenyu Li ${ }^{1}$, Sheng Zhang ${ }^{1}$, Gang $\mathrm{Wu}^{1}$ and Rui Meng ${ }^{1^{*}}$

\begin{abstract}
Background: Tumor microenvironment (TME) plays a vital role in determining the outcomes of radiotherapy. As an important component of TME, vascular endothelial cells are involved in the perivascular resistance niche (PVRN), which is formed by inflammation or cytokine production induced by ionizing radiation (IR). Protein kinase CK2 is a constitutively active serine/threonine kinase which plays a vital role in cell proliferation and inflammation. In this study, we investigated the potential role of CK2 in PVRN after IR exposure.
\end{abstract}

Result: Specific CK2 inhibitors, Quinalizarin and CX-4945, were employed to effectively suppressed the kinase activity of CK2 in human umbilical vein endothelial cells (HUVECs) without affecting their viability. Results showing that conditioned medium from IR-exposed HUVECs increased cell viability of A549 and H460 cells, and the pretreatment of CK2 inhibitors slowed down such increment. The secretion of IL-8 and IL-6 in HUVECs was induced after exposure with IR, but significantly inhibited by the addition of CK2 inhibitors. Furthermore, IR exposure elevated the nuclear phosphorylated factor-KB (NF-KB) p65 expression in HUVECs, which was a master factor regulating cytokine production. But when pretreated with CK2 inhibitors, such elevation was significantly suppressed.

Conclusion: This study indicated that protein kinase CK2 is involved in the key process of the IR induced perivascular resistant niche, namely cytokine production, by endothelial cells, which finally led to radioresistance of non-small cell lung cancer cells. Thus, the inhibition of CK2 may be a promising way to improve the outcomes of radiation in nonsmall cell lung cancer cells.

Keywords: Protein kinase CK2, lonizing radiation, Non-small cell lung cancer, NF-kB, Perivascular resistance niche (PVRN)

\footnotetext{
*Correspondence: mengruivip@163.com

${ }^{1}$ Cancer Center, Union Hospital, Tongji Medical College, Huazhong

University of Science and Technology, Wuhan 430022, China

Full list of author information is available at the end of the article
} 


\section{Introduction}

Lung cancer remains the leading cause of morbidity and mortality worldwide. Radiotherapy is one of the main treatment options for lung cancer of various stage and pathological type [1], which significantly increases the local control rate as well as to improve survival. However, the intrinsic radioresistance of cancer cells and recurrences of tumors in the previous radiation field still exist [2]. Therefore, it is crucial to investigate the mechanism of radioresistance and to find novel therapeutic strategies to improve patient outcomes.

Previous works have concentrated on understanding radioresistance by focusing on mechanisms within tumor cells. Although recent evidence suggests that the tumor microenvironment (TME) plays an important role in determining outcomes of radiotherapy [3-5]. TME includes tumor cells, fibroblasts and immune cells, as well as secretory products (such as cytokines and chemokines) and non-cellular components in extracellular matrix of these cells. It has been reported that the perivascular resistance niche (PVRN), which is formed by paracrine cytokine production in endothelial cells after radiation, can regulate radioresistance of tumor cells $[6,7]$. However, the exact underlying molecular mechanisms of PVRN are largely unknown.

A number of studies have shown that nuclear transcription factor (NF-kB) regulates the expression of a series of cytokine genes and is considered to be the center of molecular regulation of cytokine release [8]. $\mathrm{NF}-\mathrm{KB}$ is widely expressed in various vascular endothelial tissues [9], and can be activated by radiation and involved in the adaptive response of cells to radiation [10]. Radiation can increase the concentration of a variety of cytokines including IL-8 and IL-6. IL- 6 was reported to be highly expressed in tumors and can promote the growth of tumors and increase tumor resistant to treatment [11-13]. IL-8 was imported to be implicated in many cell processes including angiogenesis, cell proliferation and metastasis [14].

Protein kinase CK2 is a highly conserved serine/threonine protein kinase [15]. It is able to phosphorylate more than three hundreds different substrates, including NF- $\kappa B$ [16]. CK2 can phosphorylate p65 subunit of NF- $\kappa B$ [17-19], as well as IкB- $\alpha$ [20], which is degraded after phosphorylation, to promote NF- $\mathrm{kB}$ nuclear translocation and activate its transcriptional activity [21].

In our present study, we investigated the involvement of vascular endothelial cells in radioresistance of NSCLC cells following exposure to ionizing radiation (IR) and further explored the effect of CK2 inhibition on this process.

\section{Materials and methods}

\section{Cell culture and reagents}

Human non-small cell lung cancer cells A549, H460 and human umbilical vein endothelial cells (HUVECs) was purchased from the Chinese Academy of Science Committee on Type Culture Collection Cell Bank (Shanghai, China). Cells were cultured in $5 \% \mathrm{CO}_{2}$ at $37{ }^{\circ} \mathrm{C}$. A549 and H460 cells were cultured in RPMI 1640 (Gibco, CA, USA) supplemented with $10 \%$ FBS (fetal bovine serum, Gibco, CA, USA) and $1 \%$ penicillin/streptomycin (Gibco, CA, USA). HUVECs cells were cultured in endothelial cell medium (Sciencell, USA), Quinalizarin was purchased form Merck (Germany), CX-4945 was purchased from Selleck (Houston, TX, USA).

\section{Ionizing radiation (IR) treatment}

$\mathrm{X}$-rays were generated by a linear accelerator (Primus K, Siemens, Munich, Bayern, Germany) with $6 \mathrm{MV}$ photons $/ 100 \mathrm{~cm}$ focus-surface distance and a dose rate of $2.0 \mathrm{~Gy} / \mathrm{min}$.

\section{In vitro kinase assay}

HUVECs were treated with DMSO, $25 \mu \mathrm{M}$ Quinalizairn or $10 \mu \mathrm{M} \mathrm{CX}-4945$ for $1 \mathrm{~h}, 6 \mathrm{~h}$ or $24 \mathrm{~h}$, lysed and extracts were used in a kinase filter assay. The kinase assay was performed as described previously [22].

\section{Western blot}

Nuclear and cytosolic proteins of HUVECs were extracted using the nuclear and cytoplasmic protein extraction kit (Beyotime, Shanghai, China) or the total proteins were extracted, separated on SDS gel and then transferred onto PVDF membranes. After blocked with $5 \%$ nonfat dry milk, the blots were incubated with antiCK $2 \alpha, \alpha^{\prime}$ and $\beta$ (generated as described previously [23] and was a gift from Prof. Dr. Mathias Montenarh, Universität des Saarlandes, Germany), anti-p65, anti-p-p65, anti-histone H3 (Santa Cruz Biotechnology, CA, USA) and anti-GAPDH (Abcam, Cambridge, UK) antibodies at $4{ }^{\circ} \mathrm{C}$ overnight. The blots were washed and incubated with secondary antibody (Boster, Wuhan, China). After addition of chemiluminescent reagent, the blots were exposed to imaging system (UVP ChemiDoc-It, USA). The intensities of the bands were detected by Image J.

\section{CCK8 assay}

HUVECs were pretreated with complete medium, DMSO, $25 \mu \mathrm{M}$ Quinalizarin or $10 \mu \mathrm{M}$ CX-4945 for $6 \mathrm{~h}$, then exposed to 4 Gy IR. The medium was replaced with fresh one before IR. After $24 \mathrm{~h}$, the conditioned medium was collected and filtered, then applied to $4 \mathrm{~Gy}$ irradiated A549 and H460 cells in 96-well plants. Cell 
viability was measured by cell counting kit-8 (CCK8) assay after $72 \mathrm{~h}$ or $96 \mathrm{~h}$. After indicated treatment cells were incubated with CCK8 solution (Boster, Wuhan, China) for $1 \mathrm{~h}$ at $37{ }^{\circ} \mathrm{C}$, then absorbance was detected at $450 \mathrm{~nm}$ by a multimode plate reader (EnSpire, PerkinElmer, USA).

\section{Immunofluorescence microscopy}

HUVECs were seeded onto cover slips, then pretreated with complete medium, DMSO, $25 \mu \mathrm{M}$ Quinalizairn or $10 \mu \mathrm{M}$ CX-4945 then irradiated with a dose of $4 \mathrm{~Gy}$. After $6 \mathrm{~h}$ or $24 \mathrm{~h}$, cells were fixed with $4 \%$ formalin, permeabilized with $5 \%$ Triton-X for 20 min on ice, blocked with 5\% BSA for 30 min and stained with anti-p65, p-p65 (Santa Cruz Biotechnology, CA, USA) or anti-CK2 $\alpha$ antibody at $4{ }^{\circ} \mathrm{C}$ overnight. After washing by PBS, cells were incubated with $\mathrm{Cy} 3$ or FITC-conjugated secondary antibody (Boster, Wuhan, China) for $1 \mathrm{~h}$ avoid light. Cell nuclei were stained with DAPI for $10 \mathrm{~min}$. Photographs were taken by a confocal microscope (Olympus, Tokyo, Japan).

\section{Cytometric bead array}

HUVECs were pretreated with complete medium, DMSO, $25 \mu \mathrm{M}$ Quinalizairn or $10 \mu \mathrm{M}$ CX-4945 then irradiated with a dose of $4 \mathrm{~Gy}$. The medium was replaced with fresh one before IR and the supernatants were collected $24 \mathrm{~h}$ after radiation. IL-8, IL-1 $\beta$, IL-6, IL-10, TNF- $\alpha$, IL-12p70 concentrations were measured by the cytometric bead array (CBA) kit (BD Biosciences). $10 \mu \mathrm{l}$ of each capture beads were added into $50 \mu \mathrm{l}$ of each sample then mixed with $50 \mu \mathrm{PE}$ detection reagent. After $3 \mathrm{~h}$ incubation at room temperature avoid light, samples were then washed once with wash buffer, resuspended in $300 \mu \mathrm{l}$ wash buffer and tested on a flow cytometer FACScan (BD Biosciences). Finally, data were analyzed by CBA software (BD Biosciences).

\section{Statistical analysis}

Data were shown as mean $\pm S D$ of at lest three individual experiments. Student's $t$ test or one-way ANOVA followed by Tukey's test was used for statistical analyses, and $\mathrm{p}<0.05$ was considered statistically significant.

\section{Results}

Effect of Quinalizarin and CX-4945 on CK2 kinase activity and cell viability in HUVECs

In the first step of the experiment, we applied two specific CK2 inhibitors, Quinalizarin and CX-4945 [24-26]. HUVECs were exposed to $25 \mu \mathrm{l}$ Quinalizairn or $10 \mu \mathrm{l}$ CX-4945 for $1 \mathrm{~h}, 6 \mathrm{~h}$ or $24 \mathrm{~h}$. The results proved that both inhibitors decreased the activity of CK2 by about $50 \%$ or more at all these three time points (Fig. 1a, *** $<<0.01$, $* *: \mathrm{p}<0.001)$. And both Quinalizarin and CX-4945 did not
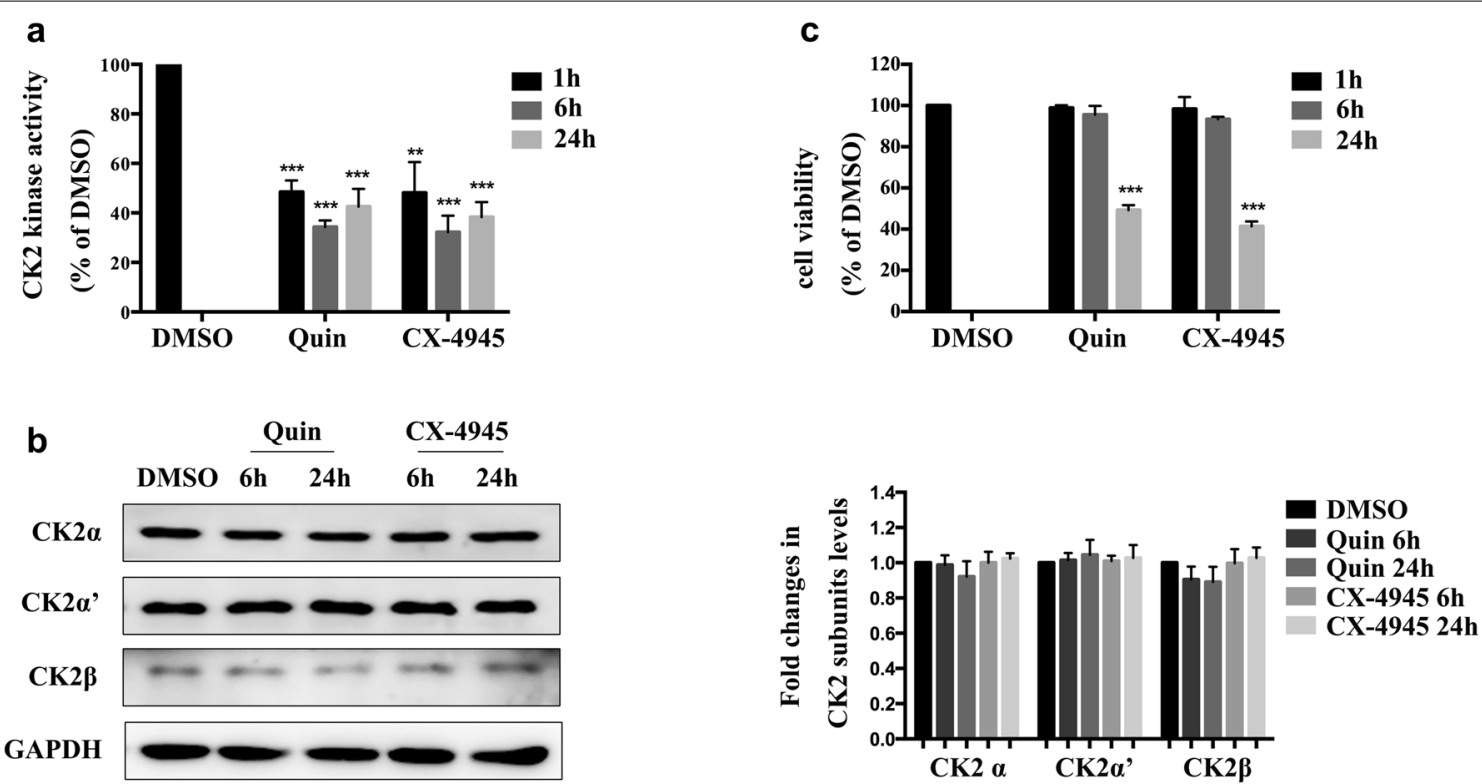

Fig. 1 The effect of Quinalizarin and CX-4945 on CK2 kinase activity and cell viability in human endothelial cells. a HUVECs were treated with DMSO, $25 \mu \mathrm{M}$ Quinalizarin, or $10 \mu \mathrm{M}$ CX-4945 for $1 \mathrm{~h}, 6 \mathrm{~h}$, or $24 \mathrm{~h}$. After cell lysis, in vitro kinase assay was conducted to measure CK2 kinase activity. Mean \pm SD were calculated for three independent experiments $\left({ }^{* *} p<0.01,{ }^{* * *} p<0.001\right)$. $\mathbf{b}$ Protein expressions of CK2 $a, a^{\prime}$ and $\beta$ subunits in HUVECS were assessed by Western blot. c HUVECs were treated as described above. Cell viability was determined by CCK 8 assay. Mean \pm SD were calculated for three independent experiments $\left({ }^{* *} p<0.001\right)$ 
affect the protein expression of CK $2 \alpha, \alpha^{\prime}$ and $\beta$ subunits (Fig. 1b). CCK8 assay was conducted in order to determine the cell viability after CK2 inhibition. As shown in Fig. 1c, Quinalizarin and CX-4945 did not affect the viability of HUVECs at $1 \mathrm{~h}$ and $6 \mathrm{~h}$, but at $24 \mathrm{~h}$ both of two CK2 inhibitors significantly reduced the cell viability $\left({ }^{* * * * *} \mathrm{p}<0.001\right)$. Therefore, in the following experiments we chose $6 \mathrm{~h}$ as the best time point when pretreated the HUVECs with CK2 inhibitors, since it markedly suppressed the activity of CK2 without significantly affect the viability of cells.

\section{Inhibition of CK2 in HUVECs reverses its ionizing radiation} (IR)-induced viability-promoting capacity to non-small cell lung cancer (NSCLC) cells after IR

As long been considered that tumor microenvironment (TME) affects the radiosensitivity of tumor cells and the endothelial cells are important components of the TME. We first investigated the role of endothelial cells on the resistance niche of NSCLC cells after exposure to IR. HUVECs were applied and were pretreated with complete medium, DMSO, Quinalizarin or CX-4945 for $6 \mathrm{~h}$ and then exposed to IR, finally the supernatant from HUVECs was collected, filtered and applied to irradiated A549 or H460 cells. As shown in Fig. 2, incubation with the supernatant from the IR-exposed HUVECs for $72 \mathrm{~h}$ or $96 \mathrm{~h}$ enhanced the cell viability of irradiated A549 and H460 cells as compared with the DMSO group $(\mathrm{p}=0.0022, \mathrm{p}=0.0013$, for A549; $\mathrm{p}=0.0028, \mathrm{p}=0.0203$, for H460). However, pretreatment of HUVECs with both Quinalizarin or CX-4945 obviously slowed down such cell viability increment at $72 \mathrm{~h}(\mathrm{p}=0.0115, \mathrm{p}<0.0001$, for A549; $\mathrm{p}=0.0432, \mathrm{p}=0.0074$, for $\mathrm{H} 460$ ) and $96 \mathrm{~h}$ $(\mathrm{p}=0.0315, \mathrm{p}=0.0017$, for A549; $\mathrm{p}=0.0077, \mathrm{p}=0.0030$, for H460). Collectively, these results indicated that endothelial cells, such as HUVECs, when exposed to IR could secrete and form a microenvironment or niche to promote the cell viability of NSCLC cells. Specific CK2 inhibitors could reverse such promotion environment and finally reduced the growth enhancement of NSCLC cells.

\section{Inhibition of CK2 decreased IR induced IL-8 and IL-6 secretion in HUVECs}

To further elucidate the exact cytokine produced by HUVECs to form the above mentioned resistant niche, we, in the next step, measured the expression of IL-8, IL-1 $\beta$, IL-6, IL-10, TNF- $\alpha$, IL-12p70 in the supernatant of HUVECs after IR exposure. As shown in Fig. 3a, after exposed to IR the expression of IL- 8 and IL- 6 was significantly elevated $(\mathrm{p}<0.0001, \mathrm{p}<0.0001)$. In order to check whether CK2 was involved in the release process, the specific CK2 inhibitor was applied. Results showing that either Quinalizarin or CX-4945, could markedly decrease the increment of IL- 8 and IL- 6 production induced by IR $(\mathrm{p}<0.0001, \mathrm{p}<0.0001$, for IL-8; $\mathrm{p}=0.0004, \mathrm{p}<0.0001$, for IL-6), with CX-4945 had the greatest release inhibition effect (Fig. 3b, c). Collectively, these results suggested that IR exposure induced IL- 8 and IL- 6 production in endothelial cells which could be markedly affected by CK2 inhibition, indicating a possible role of CK2 in cytokine production after IR exposure.

\section{Inhibition of CK2 inhibition decreased IR induced phosphorylated p65 expression in HUVECs}

To further explore the exact role of CK2 in endothelial cells on forming the resistant niche of NSCLC cells after IR, we detected the relationship between CK2 and $\mathrm{NF}-\kappa \mathrm{B}$, which was considered as the master molecule in cytokine production. The subcellular localization, namely shuttling from cytoplasm to nucleus, of p65 or the expression of phosphorylated p65, as the indication
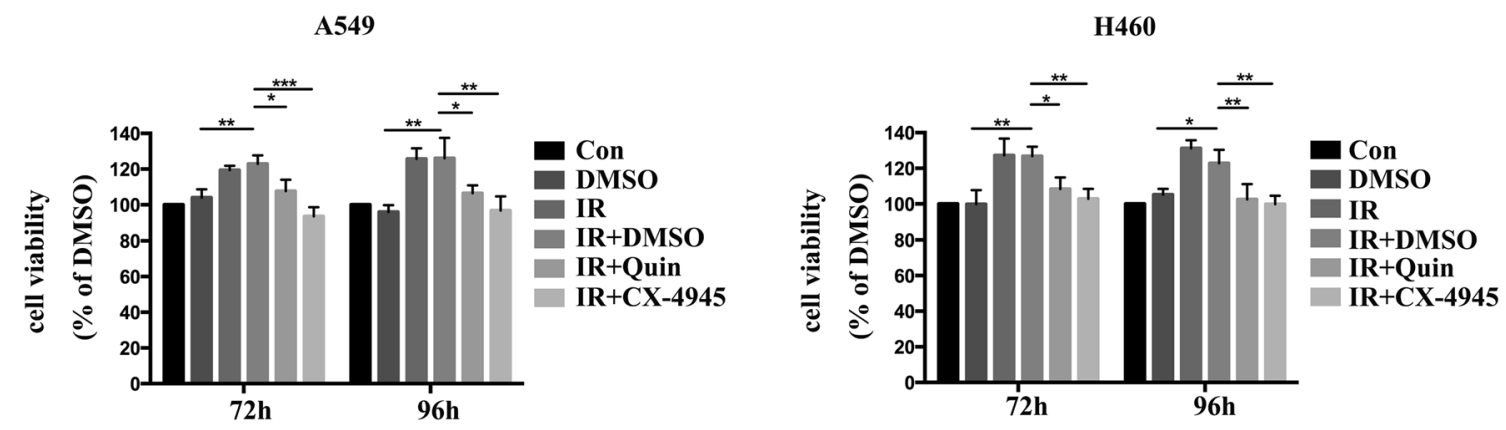

Fig. 2 Inhibition of CK2 in HUVECs reverses its ionizing radiation (IR)-induced viability-promoting capacity to non-small cell lung cancer (NSCLC) cells after IR. HUVECs were pretreated with complete medium, DMSO, $25 \mu \mathrm{M}$ Quinalizarin or $10 \mu \mathrm{M}$ CX-4945 for $6 \mathrm{~h}$, then exposed to 4 Gy IR. The medium was replaced with fresh one before IR. After $24 \mathrm{~h}$, the conditioned medium was collected and filtered, then applied to 4 Gy irradiated A549 and $\mathrm{H} 460$ cells, and continuously cultured for $72 \mathrm{~h}$ or $96 \mathrm{~h}$, then cell viability was measured by CCK8 assay. Mean \pm SD were calculated for three independent experiments $\left({ }^{*} p<0.05,{ }^{* *} p<0.01,{ }^{* * *} p<0.001\right)$ 
a
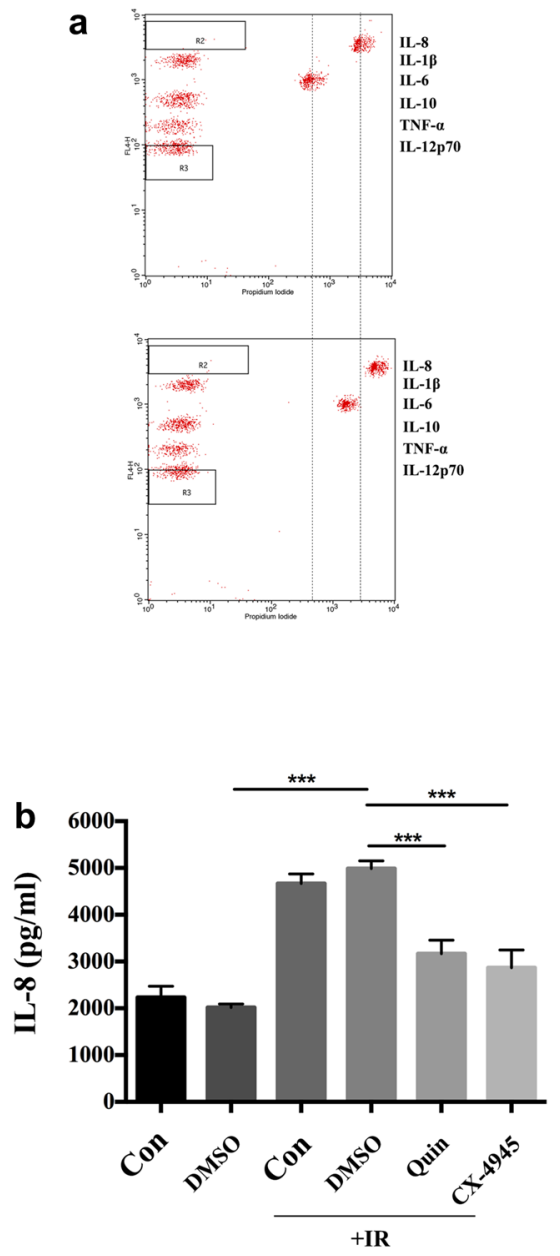

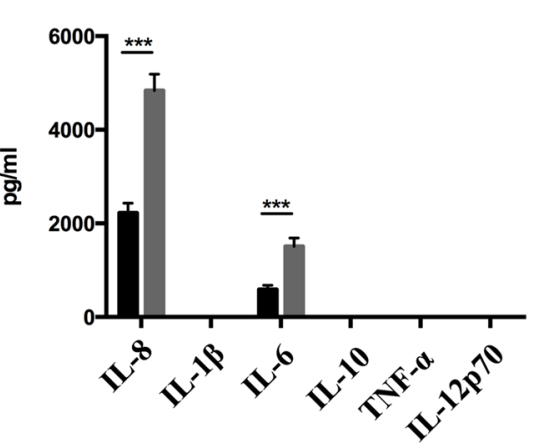

C

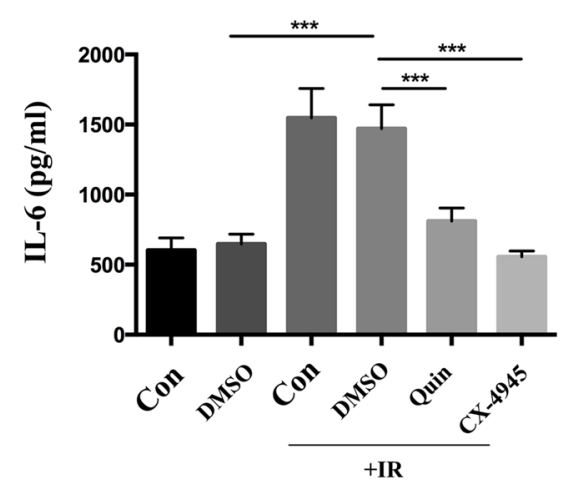

Fig. 3 CK2 inhibition decreased IR induced IL-8 and IL-6 secretion. a HUVECs was exposed to 4 Gy IR. Conditioned medium was collected $24 \mathrm{~h}$ after radiation. Then the concentration of IL-8, IL-1 $\beta, I L-6, I L-10, T N F-a, I L-12 p 70$ were detected using a CBA kit. Mean \pm SD were calculated for three independent experiments (*** ${ }^{*}<0.001$ ). HUVECs were pretreated with complete medium, DMSO, $25 \mu \mathrm{M}$ Quinalizarin or $10 \mu \mathrm{M} C X-4945$ for $6 \mathrm{~h}$, then exposed to 4 Gy IR. Conditioned medium was collected $24 \mathrm{~h}$ after radiation. Concentration of $\mathbf{b} \mid \mathrm{L}-8$ and $\mathbf{c} \mid \mathrm{L}-6$ were detected using a CBA kit. Mean $\pm S D$ were calculated for three independent experiments $(* * p<0.001$ )

of NF-kB activation, in endothelial cells was detected after exposed to IR and/or CK2 inhibition. HUVECs were pretreated with CK2 inhibitors for $6 \mathrm{~h}$, then exposed to IR. Cells were fixed and immunofluorecence assays were conducted thereafter. As illustrated in Fig. 4a, p65 localized solely in the cytoplasm in untreated HUVECs. IR exposure did not affect the localization of p65 in HUVECs and the result was consistent with the Western bolt assay (Fig. 4c). However, the combination of IR and CK2 inhibitors seems to slightly increase the expression of p65 in the nucleus at $6 \mathrm{~h}$ after IR (Fig. 4a). In addition, the CK2 catalytic subunit $C K 2 \alpha$ was also detected. It was shown that CK $2 \alpha$ expressed mainly in the nucleus and its subcellular localization was not affected by IR or inhibition of CK2.
The subcellular localization of phosphorylated p65 was also detected in HUVECs by the phospho-specific antibodies against the serine 529 which was regarded as a CK2 phosphorylation site [18, 27]. As shown in Fig. 4b, phosphorylated p65 was mainly expressed in the nucleus. IR exposure obviously increased the nuclear signal of phosphorylated p65, while CK2 inhibition markedly reduced its expression. We also conducted western bolt to measure the expression of p65 and phosphorylated p65, as shown in Fig. 4c, the expression levels of p-p65 were significantly increased $6 \mathrm{~h}$ or $24 \mathrm{~h}$ after exposed to IR $(\mathrm{p}<0.0001, \mathrm{p}=0.0455)$, and the treatment of both Quinalizarin and CX-4945 reduced this enhancement $(\mathrm{p}<0.0001, \mathrm{p}<0.0001$, for $6 \mathrm{~h} ; \mathrm{p}=0.0024, \mathrm{p}=0.0009$, for $24 \mathrm{~h})$. 


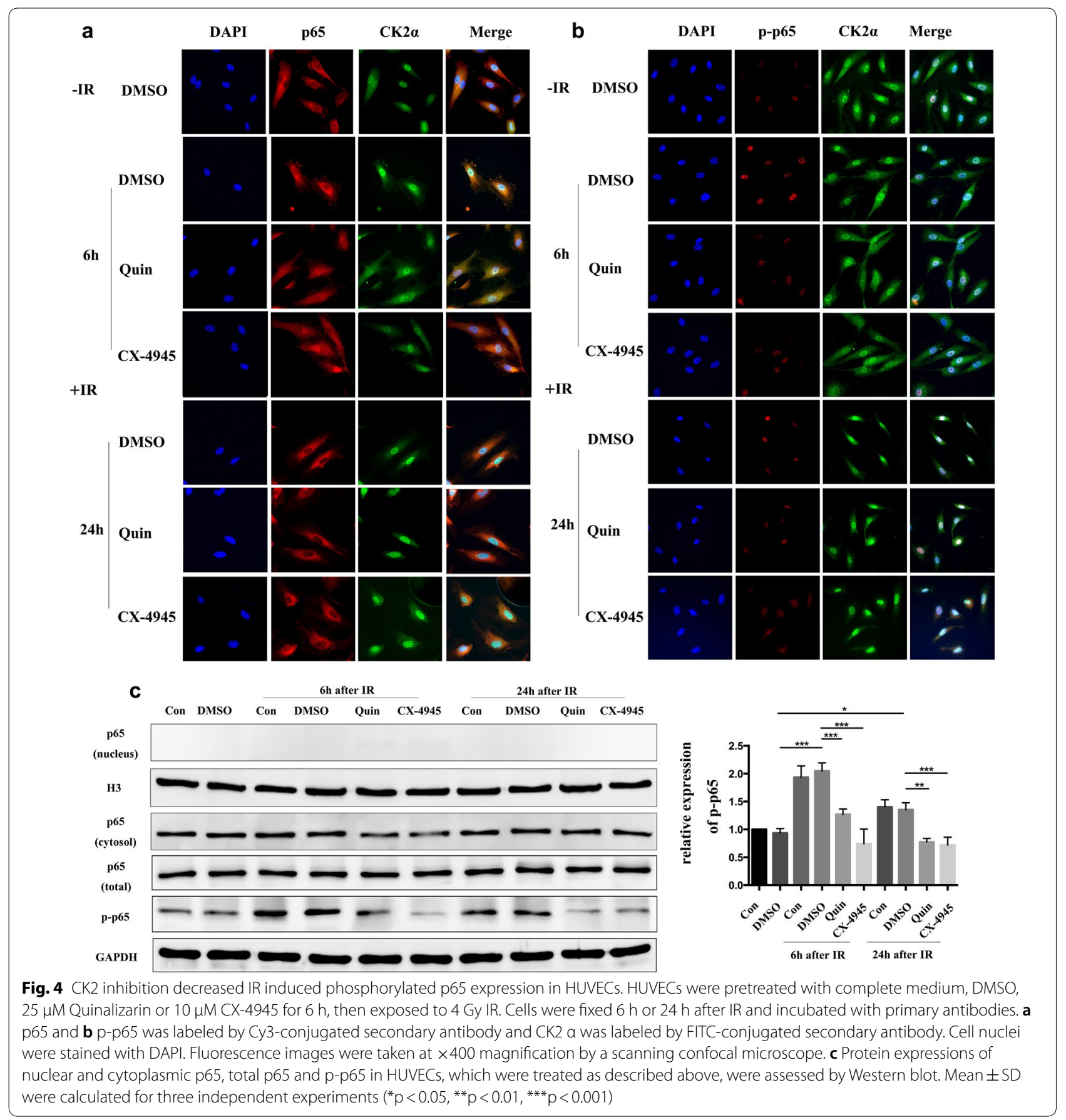

In summary, as illustrated in Fig. 5, CK2 inhibition was able to suppress the phosphorylation of p65, then reduced the increase of IL- 8 and IL- 6 in endothelial cells after exposure to IR, which destroyed the forming of the perivascular resistance niche (PVRN) and finally led to radiosensitize lung cancer cells.

\section{Discussion}

Ionizing radiation (IR) induced tumor microenvironment remodeling has a great impact on the outcomes of radiotherapy in cancer. The mechanisms underlying such process include direct contact with tumor cells and their surrounding stroma, the interaction of tumor cells and host immune cells, vascular endothelial cells or 


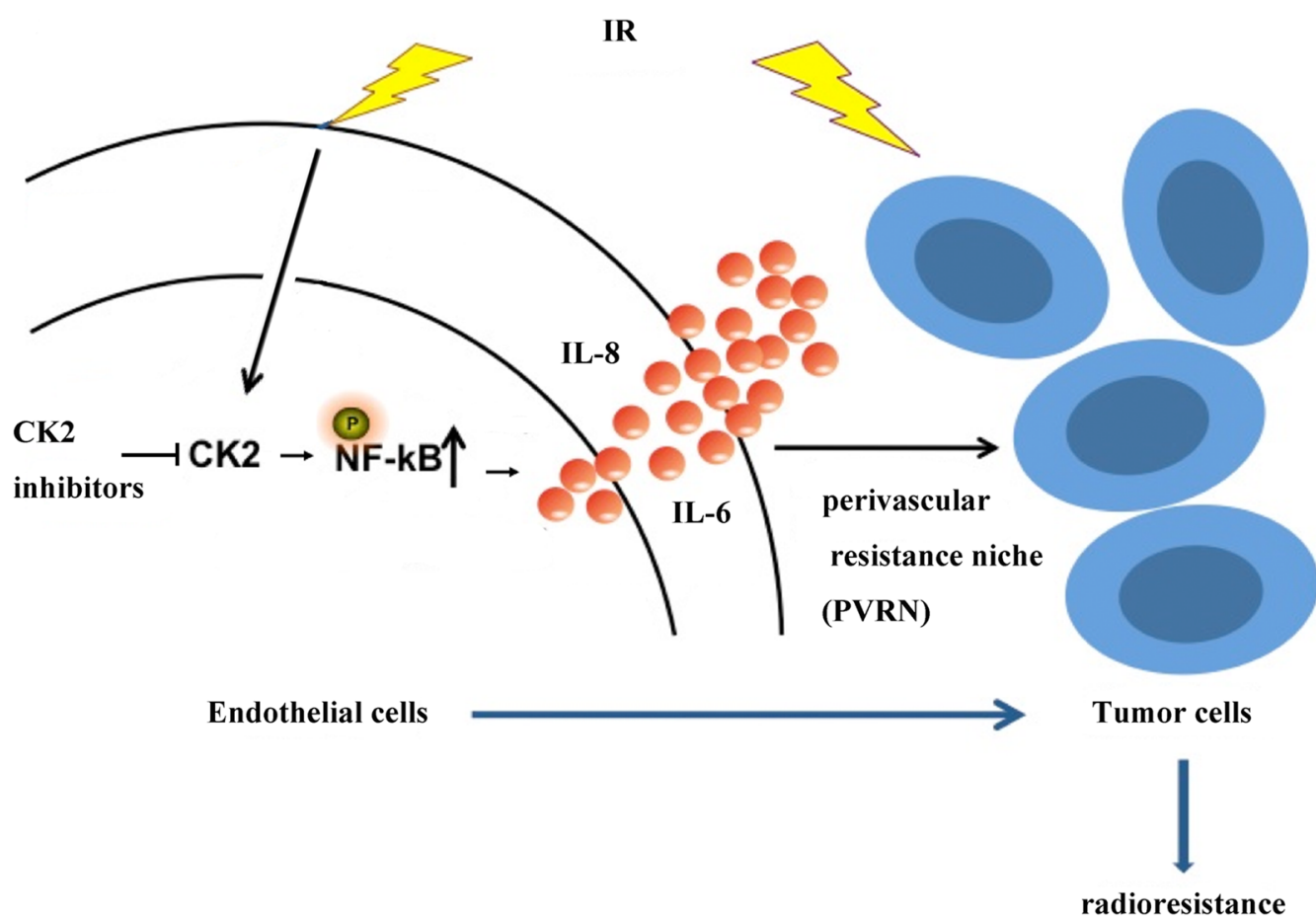

Fig. 5 Schematic representation of a putative mechanism underlying the forming of perivascular resistance niche (PVRN) after exposure to IR. CK2 inhibition suppresses the phosphorylation of NF-KB, then reduces the increase of IL-8 and IL-6 in endothelial cells after exposure to IR, which destroyed the forming of PVRN and finally leads to radiosensitize lung cancer cells ( $\rightarrow$ indicates stimulation effect, $\dashv$ means inhibitory effect)

fibroblasts, and the paracrine effects of cytokines' secretion [3].

Protein kinase CK2 is reported to be highly expressed in lung cancer cells and tissues [28, 29]. The inhibition of CK2 in lung cancer cells effectively suppresses the proliferation of tumor cells [24, 30-33]. Down regulation of CK2 is also reported to enhance the radiosensitivity of nasopharyngeal carcinoma cells [34]. In addition, in our previous study we verified that CK2 inhibition could radiosensitize lung cancer cells [22]. However, these researches focused on mechanisms solely within tumor cells, in this study, we explored the role of CK2 in IR induced tumor microenvironment remodeling process and further investigated the effects of endothelial CK2 inhibition on the radiosensitivity of lung cancer cells. Our results found that HUVECs, when exposed to IR could secrete and form a microenvironment or niche to promote the cell viability of NSCLC cells. Specific CK2 inhibitors, Quinalizarin and CX4945, could reverse such promotion environment and finally reduced the paracrine growth enhancement of NSCLC cells.

Regarding the exact mechanisms underlying such process, in the present study we found that after exposed to IR, secretion of cytokines such as IL-8 and IL-6 significantly elevated from endothelial cells, which could be markedly affected by CK2 inhibition (Fig. 3b, c).
Similarly, as previously reported in other cell lines, IL-6 was a multifunctional cytokine which was induced by radiation $[35,36]$ and played pivotal role in the process of radioresistance [37]. IL-8 was also described in nasopharyngeal carcinoma cells to be a crucial player in mediating radiation response and induction of radioresistance [38]. In addition, there was also evidence showing that IL- 6 expression could be modulated by CK 2 in inflammatory breast cancer cells [39]. IL-8 and IL- 6 was reported to increase the cell proliferation of NSCLC cells. It indicated that the increased cell viability of NSCLC cells cocultured with irradiated HUVECs supernatant (Fig. 2) was associated with the enhanced secretion of IL- 8 and IL-6 after irradiation. Our results were to date the first to show, in endothelial cells, the irradiation induced expression of cytokines such as IL-8 and IL- 6 was controlled or mediated by protein kinase CK 2 .

A growing body of literature proves that NF- $\mathrm{KB}$ activation can increase the secretion of major inflammatory factors, including IL-6, IL-8, TNF- $\alpha$, IL-1, etc. Such inflammatory factors are also act as potent activators for NF- $\mathrm{kB}$. This positive feedback loop between NF- $\mathrm{KB}$ and inflammation improve cell proliferation and transformation $[40,41]$. The transcription factor $\mathrm{p} 65$ is a component of the heterodimeric NF- $\mathrm{kB}$ complex. Phosphorylation of p65 activates its transcriptional activity. Protein kinase 
CK2 is an important regulator of p65, which can phosphorylate p65 at Ser 529 to increase the transcriptional activity of it $[18,27]$. CK2 can also phosphorylate I $\kappa \mathrm{B} \alpha$ to promote the degradation of I $\mathrm{I} B \alpha$ and activate NF- $\mathrm{kB}$ [20]. In the current study, we detected an increase of phosphorylated p65 in HUVECs at $6 \mathrm{~h}$ and $24 \mathrm{~h}$ after IR. And the pretreatment of either CX-4945 or Quinalizarin suppressed it (Fig. 4b, c). In addition, we also found that CK2 inhibitors slightly enhanced the level of nuclear p65. This hypo-phosphorylation caused accumulation of p65 in the nucleus was mainly due to a defective ІкB $\alpha$ synthesis [42]. This was in line with the results published by Ampofo et al. that CK2 inhibition suppresses TNF- $\alpha$ induced NF- $\mathrm{kB}$ p 65 phosphorylation at Ser529 in Human Dermal Microvascular Endothelial Cells [43].

\section{Conclusion}

CK2 inhibition can reverse the perivascular resistance niche (PVRN) after IR by reduces the IR enhanced phosphorylation of p 65 and the expression of IL- 8 and IL- 6 in HUVECs. This might be a promising way for CK2 inhibitors to enhance the radiosensitivity of non-small cell lung cancer cells.

\section{Abbreviations}

CK2: protein kinase CK2; PVRN: perivascular resistant niche; NSCLC: non-small cell lung cancer; TME: tumor microenvironment; IR: ionizing radiation; HUVECs: human umbilical vein endothelial cells.

\section{Authors' contributions}

RM and GW designed the research. QL, YZ, XJ and JH performed the experiments and analyzed the data. $Q L$ and $K L$ and $X Z$ interpreted the results and wrote the draft of the manuscript. BW, ZL and SZ wrote the final version of the manuscript. All authors discussed the results and commented on the manuscript. All authors read and approved the final manuscript.

\section{Author details}

${ }^{1}$ Cancer Center, Union Hospital, Tongji Medical College, Huazhong University of Science and Technology, Wuhan 430022, China. ${ }^{2}$ Pharmacy Department, Union Hospital, Tongji Medical College, Huazhong University of Science and Technology, Wuhan 430022, China.

\section{Acknowledgements}

We sincerely thank Prof. Mathias Montenarh from Medizinische Biochemie und Molekular biologie, Universität des Saarlandes, Gebäude 44, 66424 Homburg, Germany for his time, support and valuable suggestions throughout the development of this paper.

\section{Competing interests}

The authors declare that they have no competing interests.

\section{Availability of data and materials}

All data generated or analyzed during this study are included in this published article.

\section{Consent for publication}

All the authors listed have approved the manuscript that is enclosed.

\section{Ethics approval and consent to participate}

Not applicable.

\section{Funding}

This study was supported by the Foundation for Fostering Key Talents from Middle-aged and Young Medical Personnel in Wuhan (2016 No. 02.05.17030006), Natural Science Foundation of Hubei Province of China (NO. 2016cfb426), National Natural Science Foundation of China (No. 81101690 to Rui Meng and No. 81672979 to Gang Wu).

\section{Publisher's Note}

Springer Nature remains neutral with regard to jurisdictional claims in published maps and institutional affiliations.

Received: 2 November 2018 Accepted: 6 April 2019

Published online: 16 April 2019

\section{References}

1. De Ruysscher D, Belderbos J, Reymen B, van Elmpt W, van Baardwijk A, Wanders R, Hoebers F, Vooijs M, Ollers M, Lambin P. State of the art radiation therapy for lung cancer 2012: a glimpse of the future. Clin Lung Cancer. 2013;14(2):89-95.

2. Shi JG, Shao HJ, Jiang FE, Huang YD. Role of radiation therapy in lung cancer management-a review. Eur Rev Med Pharmacol Sci. 2016;20(15):3217-22.

3. Hellevik T, Martinez-Zubiaurre I. Radiotherapy and the tumor stroma: the importance of dose and fractionation. Front Oncol. 2014;4:1.

4. Barcellos-Hoff MH, Park C, Wright EG. Radiation and the microenvironment-tumorigenesis and therapy. Nat Rev Cancer. 2005;5(11):867-75.

5. Chargari C, Clemenson C, Martins I, Perfettini JL, Deutsch E. Understanding the functions of tumor stroma in resistance to ionizing radiation: emerging targets for pharmacological modulation. Drug Resist Updat. 2013;16(1-2):10-21.

6. Tavora B, Reynolds LE, Batista S, Demircioglu F, Fernandez I, Lechertier T, Lees DM, Wong PP, Alexopoulou A, Elia G, et al. Endothelial-cell FAK targeting sensitizes tumours to DNA-damaging therapy. Nature. 2014;514(7520):112-6.

7. Hambardzumyan D, Becher OJ, Rosenblum MK, Pandolfi PP, ManovaTodorova K, Holland EC. PI3 K pathway regulates survival of cancer stem cells residing in the perivascular niche following radiation in medulloblastoma in vivo. Genes Dev. 2008;22(4):436-48.

8. Hoesel B, Schmid JA. The complexity of NF-kappaB signaling in inflammation and cancer. Mol Cancer. 2013;12:86.

9. Hoppe CC. Inflammatory mediators of endothelial injury in sickle cell disease. Hematol Oncol Clin North Am. 2014;28(2):265-86.

10. Ahmed KM, Li JJ. NF-kappa B-mediated adaptive resistance to ionizing radiation. Free Radic Biol Med. 2008:44(1):1-13.

11. Schafer ZT, Brugge JS. IL-6 involvement in epithelial cancers. J Clin Invest. 2007;117(12):3660-3.

12. Culig Z, Puhr M. Interleukin-6: a multifunctional targetable cytokine in human prostate cancer. Mol Cell Endocrinol. 2012;360(1-2):52-8.

13. Guo Y, Xu F, Lu T, Duan Z, Zhang Z. Interleukin- 6 signaling pathway in targeted therapy for cancer. Cancer Treat Rev. 2012;38(7):904-10.

14. Luppi F, Longo AM, de Boer WI, Rabe KF, Hiemstra PS. Interleukin-8 stimulates cell proliferation in non-small cell lung cancer through epidermal growth factor receptor transactivation. Lung Cancer. 2007;56(1):25-33.

15. Litchfield DW. Protein kinase CK2: structure, regulation and role in cellular decisions of life and death. Biochem J. 2003;369(Pt 1):1-15.

16. Meggio F, Pinna LA. One-thousand-and-one substrates of protein kinase CK2? FASEB J. 2003;17(3):349-68.

17. Dominguez I, Sonenshein GE, Seldin DC. Protein kinase CK2 in health and disease: CK2 and its role in Wnt and NF-kappaB signaling: linking development and cancer. Cell Mol Life Sci. 2009;66(11-12):1850-7.

18. Wang D, Westerheide SD, Hanson JL, Baldwin AS Jr. Tumor necrosis factor alpha-induced phosphorylation of RelA/p65 on Ser529 is controlled by casein kinase II. J Biol Chem. 2000;275(42):32592-7.

19. Kweon SM, Wang B, Rixter D, Lim JH, Koga T, Ishinaga $H$, Chen LF, Jono $\mathrm{H}, \mathrm{Xu} \mathrm{H}$, Li JD. Synergistic activation of NF-kappaB by nontypeable $H$. influenzae and S. pneumoniae is mediated by CK2, IKKbeta-IkappaBalpha, and p38 MAPK. Biochem Biophys Res Commun. 2006;351(2):368-75. 
20. Shen J, Channavajhala P, Seldin DC, Sonenshein GE. Phosphorylation by the protein kinase CK2 promotes calpain-mediated degradation of IkappaBalpha. J Immunol. 2001;167(9):4919-25.

21. Hinz M, Scheidereit C. The IkappaB kinase complex in NF-kappaB regulation and beyond. EMBO Rep. 2014;15(1):46-61.

22. Li Q, Li K, Yang T, Zhang S, Zhou Y, Li Z, Xiong J, Zhou F, Zhou X, Liu L, et al. Association of protein kinase CK2 inhibition with cellular radiosensitivity of non-small cell lung cancer. Sci Rep. 2017;7(1):16134.

23. Faust $M$, Schuster $N$, Montenarh M. Specific binding of protein kinase CK2 catalytic subunits to tubulin. FEBS Lett. 1999;462(1-2):51-6.

24. Cozza G, Mazzorana M, Papinutto E, Bain J, Elliott M, di Maira G, Gianoncelli A, Pagano MA, Sarno S, Ruzzene M, et al. Quinalizarin as a potent, selective and cell-permeable inhibitor of protein kinase CK2. Biochem J. 2009:421(3):387-95.

25. Cozza G, Venerando A, Sarno S, Pinna LA. The selectivity of CK2 inhibitor quinalizarin: a reevaluation. Biomed Res Int. 2015;2015:734127.

26. Sarno S, Papinutto E, Franchin C, Bain J, Elliott M, Meggio F, Kazimierczuk Z, Orzeszko A, Zanotti G, Battistutta R, et al. ATP site-directed inhibitors of protein kinase CK2: an update. Curr Top Med Chem. 2011;11(11):1340-51.

27. Bird TA, Schooley K, Dower SK, Hagen H, Virca GD. Activation of nuclear transcription factor NF-kappaB by interleukin-1 is accompanied by casein kinase II-mediated phosphorylation of the p65 subunit. J Biol Chem. 1997;272(51):32606-12.

28. Lin YC, Hung MS, Lin CK, Li JM, Lee KD, Li YC, Chen MF, Chen JK, Yang CT. CK2 inhibitors enhance the radiosensitivity of human non-small cell lung cancer cells through inhibition of stat3 activation. Cancer Biother Radiopharm. 2011;26(3):381-8.

29. Pornchai O, Rusch V, Talbot SG, Sarkaria I, Viale A, Socci N, Ngai I, Rao P, Singh B. Casein kinase II alpha subunit and C1-inhibitor are independent predictors of outcome in patients with squamous cell carcinoma of the lung. Clin Cancer Res. 2004;10(17):5792-803.

30. Intemann J, Saidu NE, Schwind L, Montenarh M. ER stress signaling in ARPE-19 cells after inhibition of protein kinase CK2 by CX-4945. Cell Signal. 2014;26(7):1567-75.

31. Prins RC, Burke RT, Tyner JW, Druker BJ, Loriaux MM, Spurgeon SE. CX-4945, a selective inhibitor of casein kinase-2 (CK2), exhibits anti-tumor activity in hematologic malignancies including enhanced activity in chronic lymphocytic leukemia when combined with fludarabine and inhibitors of the B-cell receptor pathway. Leukemia. 2013;27(10):2094-6.

32. Gotz C, Gratz A, Kucklaender U, Jose J. TF-a novel cell-permeable and selective inhibitor of human protein kinase CK2 induces apoptosis in the prostate cancer cell line LNCaP. Biochem Biophys Acta. 2012;1820(7):970-7.

33. Zhou Y, Li K, Zhang S, Li Q, Li Z, Zhou F, Dong X, Liu L, Wu G, Meng R. Quinalizarin, a specific CK2 inhibitor, reduces cell viability and suppresses migration and accelerates apoptosis in different human lung cancer cell lines. Indian J Cancer. 2015;52(Suppl 2):e119-24.

34. Pan X, Meng R, Yu Z, Mou J, Liu S, Sun Z, Zou Z, Wu G, Peng G. Quinalizarin enhances radiosensitivity of nasopharyngeal carcinoma cells partially by suppressing SHP-1 expression. Int J Oncol. 2016;48(3):1073-84.

35. Gao L, Li FS, Chen XH, Liu QW, Feng JB, Liu QJ, Su X. Radiation induces phosphorylation of STAT3 in a dose- and time-dependent manner. Asian Pac J Cancer Prev. 2014;15(15):6161-4.

36. Zang C, Liu X, Li B, He Y, Jing S, He Y, Wu W, Zhang B, Ma S, Dai W, et al. IL-6/STAT3/TWIST inhibition reverses ionizing radiation-induced EMT and radioresistance in esophageal squamous carcinoma. Oncotarget. 2017:8(7):11228-38

37. Matsuoka Y, Nakayama H, Yoshida R, Hirosue A, Nagata M, Tanaka T, Kawahara K, Sakata J, Arita H, Nakashima H, et al. IL-6 controls resistance to radiation by suppressing oxidative stress via the Nrf2-antioxidant pathway in oral squamous cell carcinoma. Br J Cancer. 2016;115(10):1234-44.

38. Qu JQ, Yi HM, Ye X, Li LN, Zhu JF, Xiao T, Yuan L, Li JY, Wang YY, Feng J, et al. MiR-23a sensitizes nasopharyngeal carcinoma to irradiation by targeting IL-8/Stat3 pathway. Oncotarget. 2015;6(29):28341-56.

39. Drygin $D, H_{0} C B$, Omori M, Bliesath J, Proffitt $C$, Rice R, Siddiqui-Jain A, O'Brien S, Padgett C, Lim JK, et al. Protein kinase CK2 modulates IL-6 expression in inflammatory breast cancer. Biochem Biophys Res Commun. 2011;415(1):163-7.

40. Fan Y, Mao R, Yang J. NF-kappaB and STAT3 signaling pathways collaboratively link inflammation to cancer. Protein Cell. 2013;4(3):176-85.

41. De Simone V, Franze E, Ronchetti G, Colantoni A, Fantini MC, Di Fusco D, Sica GS, Sileri P, MacDonald TT, Pallone F, et al. Th17-type cytokines, IL-6 and TNF-alpha synergistically activate STAT3 and NF-kB to promote colorectal cancer cell growth. Oncogene. 2015;34(27):3493-503.

42. Hochrainer K, Racchumi G, Anrather J. Hypo-phosphorylation leads to nuclear retention of NF-kappaB p65 due to impaired IkappaBalpha gene synthesis. FEBS Lett. 2007;581(28):5493-9.

43. Ampofo E, Rudzitis-Auth J, Dahmke IN, Rossler OG, Thiel G, Montenarh M, Menger MD, Laschke MW. Inhibition of protein kinase CK2 suppresses tumor necrosis factor (TNF)-alpha-induced leukocyte-endothelial cell interaction. Biochimica et biophysica acta. 2015;1852(10 Pt A):2123-36.
Ready to submit your research? Choose BMC and benefit from:

- fast, convenient online submission

- thorough peer review by experienced researchers in your field

- rapid publication on acceptance

- support for research data, including large and complex data types

- gold Open Access which fosters wider collaboration and increased citations

- maximum visibility for your research: over $100 \mathrm{M}$ website views per year

At BMC, research is always in progress.

Learn more biomedcentral.com/submissions 